\title{
Students Scientific Attitude in Learning Physics using Problem Based Learning Model with Experimental and Project Methods
}

\author{
Maura Trynovita Sakliressy ${ }^{1}$, Widha Sunarno ${ }^{2 *}$, Fahru Nurosyid $^{3}$ \\ ${ }^{1}$ Master of Physics Education, Postgraduate School, Universitas Sebelas Maret, Indonesia. \\ ${ }^{2}$ Departement of Physics Education, Faculty of Teacher Training and Education, Universitas Sebelas Maret, \\ Indonesia. \\ ${ }^{3}$ Departement of Physics, Faculty of Mathematics and Natural Science, Universitas Sebelas Maret, Indonesia.
}

*Corresponding Address: widhasunarno@staff.uns.ac.id

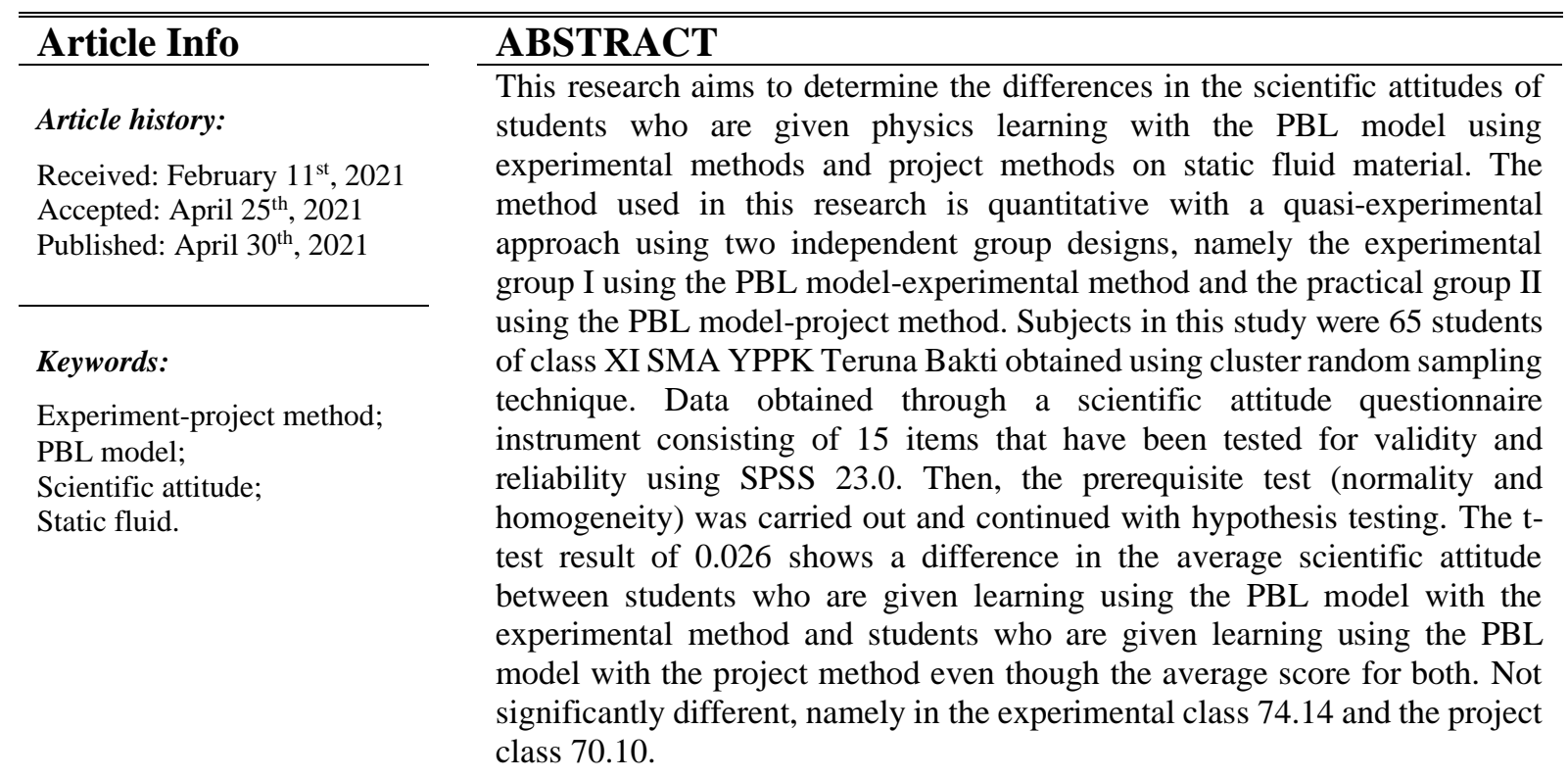

(C) 2021 Physics Education Department, UIN Raden Intan Lampung, Indonesia.

\section{INTRODUCTION}

Education is currently directed at $21 \mathrm{st}-$ century learning marked by the era of the industrial revolution 4.0. According to Abdurrahman et al., the impact of education 4.0 is technology-based development (Ramadhani et al., 2019). 21st-century learning requires students to be more active in finding out the physics concepts in various ways, such as observation, project assignments, simulations, or experiments. This is done to use scientific methods based on scientific attitudes and skills to solve the problems they face both in learning and difficulties in society. This also has an impact on the scientific perspective of students in education. Scientific attitudes can affect student achievement. This can be seen from the character of scientists (students) in conducting research (Amelia et al., 2019). According to (Pitafi et al., 2012), reactions or expressions displayed in learning according to scientific ethics can be in the form of scientific attitudes.

In the learning process, the teacher tends to pay attention to attitude assessment but does not pay attention to students' scientific attitude (Azmi et al., 2017). This is because teachers have difficulty in designing learning approaches and strategies to improve students' scientific attitudes (Widowati et al., 2017). According to Oloruntegbe \& Omoifo, one factor that can lead to low student scientific attitudes is the lack of assessment 
in students (Nugraha et al., 2020). This concurs with the interview results by a researcher with a teacher in a research school who stated that scientific attitudes are rarely carried out in learning because teachers tend to combine scientific attitude assessment with attitude assessment. Most students cannot connect the concepts learned with how the knowledge will be used in the future. This makes students use only a small part of their potential or thinking ability and makes them lazy to think independently (Setyorini et al., 2011). Efforts to solve these problems are designing assessment and learning improvements starting from learning models and methods, which are expected to make it easier for students to understand physics concepts to improve their scientific attitudes. Teachers should provide opportunities for students to develop scientific attitudes (Istikomah et al., 2010).

The learning models and methods used must direct students to be actively involved and become the center of the learning process. One of them is the PBL model. The PBL model has been widely used in learning to improve students' various abilities, skills, and scientific attitudes. This is in line with the research conducted (Arini et al., 2018) that PBL-based modules effectively improve students' problem-solving skills and scientific perspectives. A study by Satrianingsih (Satrianingsih et al., 2016) found that the PBL model positively affects cognitive abilities and attitudes towards science. The PBL model directs students to become active learners through concrete questions related to physics concepts given by the teacher. This is in line with Wilkerson \& Gijselaers, which explain that PBL is characterized by a student-centered approach and the teacher as a facilitator who presents problems as an initial stimulus in learning (Duch, Allen, \& Groh, 2001). The teacher as a facilitator can create active learning for students (Telaumbanua, 2017). According to Bound \& Feletti, the basic principle that supports the PBL concept is that learning begins with a problem, question, or puzzle that students must solve (Duch, Allen, \& Groh, 2001).

The problems that the teacher offers can be solved through a variety of methods, including experimental and project methods. Learning with the practical method leads students to do experiments to prove and experience what they know(Djamarah \& Zain, 2010). The experimental method includes a teaching mechanism, where students carry out an investigation related to a particular subject, observe it, write down the acquisition of the experiment, then the acquisition of these observations is explained in front of the class and assessed by the teacher (Roestiyah, 2012). When students in groups study using the project method, students are asked to make or work on a project together and present the project results (Suparno, 2007). Learning using the project method requires the skills to design learning activities that allow students to investigate a problem independently. This agrees with Howell and Mordini that using project methods as a means of teaching skills, use of tools, and problem-solving because these methods provide a means to increase student participation independently in the learning process (Muriithi et al., 2013). That's why the project method is very suitable for use in problem-based learning.

Based on the results of interviews with several YPPK Teruna Bakti high school students, it was admitted that they understood the concept better when they saw demonstrations working on project assignments or conducting experiments. This is in line with (Hilalliati et al., 2019), which states that if students do not do demonstrations directly, students tend to understand the concepts of physics less. Students also argue that they prefer to learn by experimenting because they experience it firsthand rather than learning to use books. This is also in line with Dahl et al., who stated that some students prefer learning based on experience rather than learning using textbooks (Hilalliati et al., 2019). However, currently, we are still in the period of the 
Covid-19 pandemic, where learning is done online. Students cannot do experiments directly in their homes because it will make it difficult for them. This is a challenge for teachers to continue implementing 21stcentury learning where participants must be more active in the learning process. Experimental activities in this pandemic situation are strenuous for students to understand concepts so that with the help of simulations, they will find it easier to understand and apply concepts.

Simulations are designed and sequenced in such a way as to give an accurate impression in experimenting (Tiwari \& Singh, 2011). Sometimes a virtual laboratory can be a choice or just a supportive learning environment for a physical laboratory (Tatli \& Ayas, 2013). Technology can help significantly increase the knowledge of teachers and students in learning physics (De Jong \& Van Joolingen, 1998). In this era, teachers have gained access to various kinds of technology to increase the effectiveness of the learning process (Maulidah \& Prima, 2018). This study uses a PhET simulation which is thought to be able to train students' scientific attitudes.

Through experimental activities and project assignments, both methods can stimulate students to be actively involved in learning so that they are expected to influence students' scientific attitudes. Scientific attitudes include aspects of learning physics that direct students positively or negatively towards an object in certain situations. A scientific perspective is needed to build the nation's character to overcome various country problems, such as student brawls, corruption, and so on (Sari et al., 2018). Learning that is designed attractively will affect student behavior because students are actively involved in learning.

Based on the results of the description above, the novelty of this research, namely that it is seen that the research (Lestari \& Projosantoso, 2016) uses the PBL model assisted by comic media, while in this study using the PBL model assisted by PhET and project assignments. Research (Hilalliati et al., 2019) learning was carried out using the GI model assisted by PhET to map students' scientific attitudes. Research by Azmi (Azmi et al., 2017) also used the PBL model with experimental methods and discussion of learning outcomes. In this research, the PBL model with the virtual experimental method $(\mathrm{PhET})$ and the project method (the task of designing tools/objects that work based on physics) to see the differences in scientific attitudes in the two methods. Therefore, this study aims to determine the differences in scientific attitudes of students who use the PBL model with experimental and project methods on static fluid material. The dimensions of scientific perspectives that are measured are curiosity, respect for facts, critical thinking, open thinking, discovery, and creativity. Static fluid materials include hydrostatic pressure, Pascal's law, and Archimedes' law.

\section{METHODS}

The method used in this research is a quantitative method with a quasiexperimental approach using two independent group designs, namely the experimental method and the project method. The following is the research flow used in this study. 


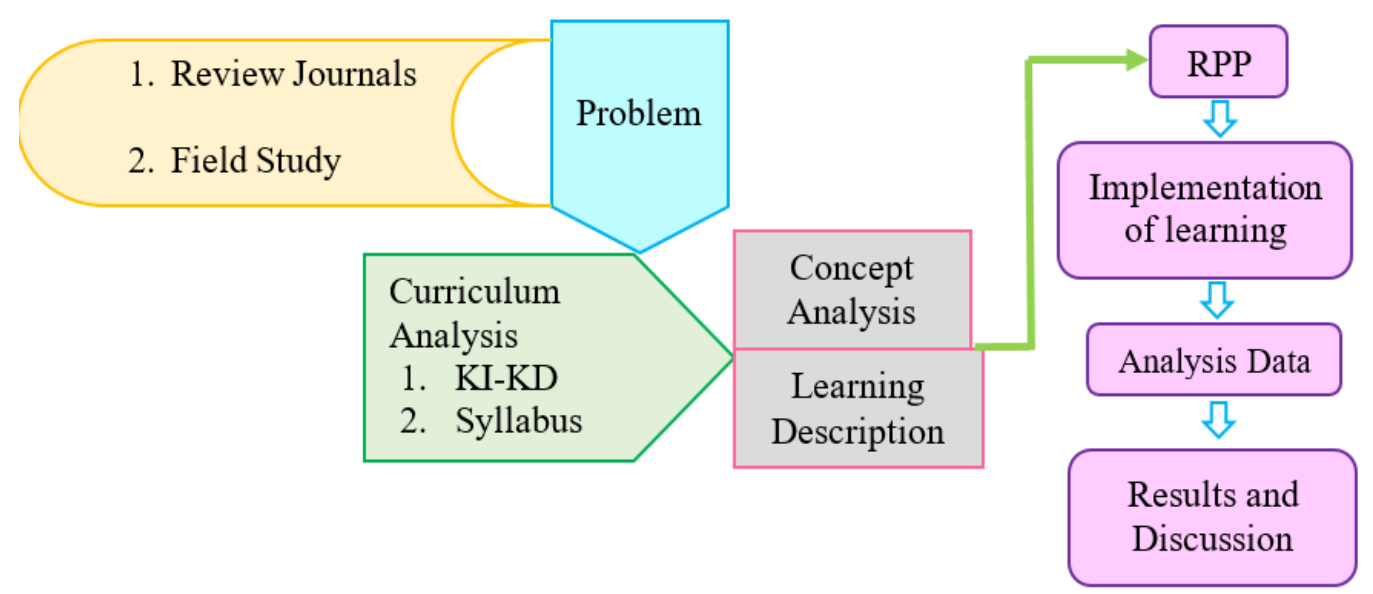

Figure 1. Research Flowchart

This study involved two groups, namely, the experimental group I using the Problem Based Learning model with the experimental method and the experimental group II using the Problem Based Learning model with the project method. The subjects in this study were 65 students of class XI SMA YPPK Teruna Bakti. Sampling was done using the cluster random sampling technique. The experimental class numbered 33 students, and the project class numbered 32 students.

Data was obtained through a scientific attitude questionnaire instrument tested for validity and reliability using SPSS 23.0. The scientific attitude questionnaire consists of 15 items using the Likert scale. Examples of questionnaire instruments used in this study can be seen in the appendix.

In this study, five dimensions were measured: curiosity, respect for facts, critical thinking, open thinking, discovery, and creativity. The following is a classification of the dimensions of scientific attitudes developed by Harlen (Anwar, 2009).

Table 1. Dimensions and Indicators of Scientific Attitude

\begin{tabular}{|c|c|}
\hline Dimensions & Indicators \\
\hline Curious & Looking for answers eagerly. \\
\hline attitude & $\begin{array}{l}\text { Paying attention to the object } \\
\text { being observed. }\end{array}$ \\
\hline \multirow{7}{*}{$\begin{array}{l}\text { Respecting the } \\
\text { facts or data }\end{array}$} & Being enthusiastic about the \\
\hline & Science process. \\
\hline & Asking every step of the activity. \\
\hline & Being objective/honest. \\
\hline & Not manipulating the data. \\
\hline & Not making bad prejudice. \\
\hline & $\begin{array}{l}\text { Making decisions based on facts. } \\
\text { Not mixing facts with opinions. }\end{array}$ \\
\hline
\end{tabular}

\begin{tabular}{|c|c|}
\hline Dimensions & Indicators \\
\hline $\begin{array}{c}\text { Fostering a } \\
\text { critical } \\
\text { thinking } \\
\text { attitude }\end{array}$ & $\begin{array}{l}\text { Doubting peers' findings. } \\
\text { Asking for any changes / new } \\
\text { things. } \\
\text { Repeating the activities carried } \\
\text { out. } \\
\text { Not ignoring data even if it's } \\
\text { small. }\end{array}$ \\
\hline $\begin{array}{l}\text { Having an } \\
\text { attitude of } \\
\text { discovery and } \\
\text { creativity }\end{array}$ & $\begin{array}{l}\text { Using facts to base conclusions. } \\
\text { Showing different reports with } \\
\text { class friends. } \\
\text { Changing opinions in response } \\
\text { to facts. } \\
\text { Using tools not as usual. } \\
\text { Suggesting new trials. } \\
\text { Describing new conclusions } \\
\text { from observations. }\end{array}$ \\
\hline $\begin{array}{l}\text { Having an } \\
\text { open-minded } \\
\text { attitude and } \\
\text { cooperation }\end{array}$ & $\begin{array}{l}\text { Respecting the opinions/findings } \\
\text { of others. } \\
\text { Wanting to change your opinion } \\
\text { if the data is lacking. } \\
\text { cooperating to receive advice } \\
\text { from friends. } \\
\text { Not feeling right all the time. } \\
\text { Assuming any conclusions are } \\
\text { tentative. } \\
\text { Participating in groups actively. }\end{array}$ \\
\hline $\begin{array}{l}\text { Having an } \\
\text { attitude of } \\
\text { persistence }\end{array}$ & $\begin{array}{l}\text { Keep researching after the } \\
\text { "novelty" is gone. }\end{array}$ \\
\hline
\end{tabular}

After the data collected is analyzed using descriptive analysis techniques in the form of a percentage calculation that can be calculated using the following equation 1, (Riduwan, 2015).

Remarks:

$$
A P=\frac{R}{S M} \times 100 \%
$$

$\mathrm{AP}=$ percent value sought

$\mathrm{R}=$ score obtained 
$\mathrm{SM}=$ ideal maximum score

The student's scientific attitude on an interval scale with two categories, namely high and low. The scientific attitude of students is in a high category if the percentage score of students' scientific attitudes is $\geq$ the mean score of the percentage of scientific attitudes, while the scientific attitude of students is in a low category if the percentage score of students' generic science skills is $<$ the mean score of the percentage of students' scientific attitudes.

The data from the calculation of the scientific attitude questionnaire in the experimental class and project class were then carried out by the prerequisite test using SPSS 23.0, normality using the Shapiro-Wilk analysis, and homogeneity Levene Test.
After that, it was continued with hypothesis testing using the T-test.

\section{RESULTS AND DISCUSSION}

The results of this study are divided into two, namely, the analysis of the scientific attitude questionnaire data between the experimental class and the project and the achievement of scientific attitudes in learning.

\section{The Scientific Attitude of the} Experiment Class and Project Class

Following are the results of the analysis and discussion of research data. Where Figure 2 shows the average results of the scientific attitude of the experimental class and project class.

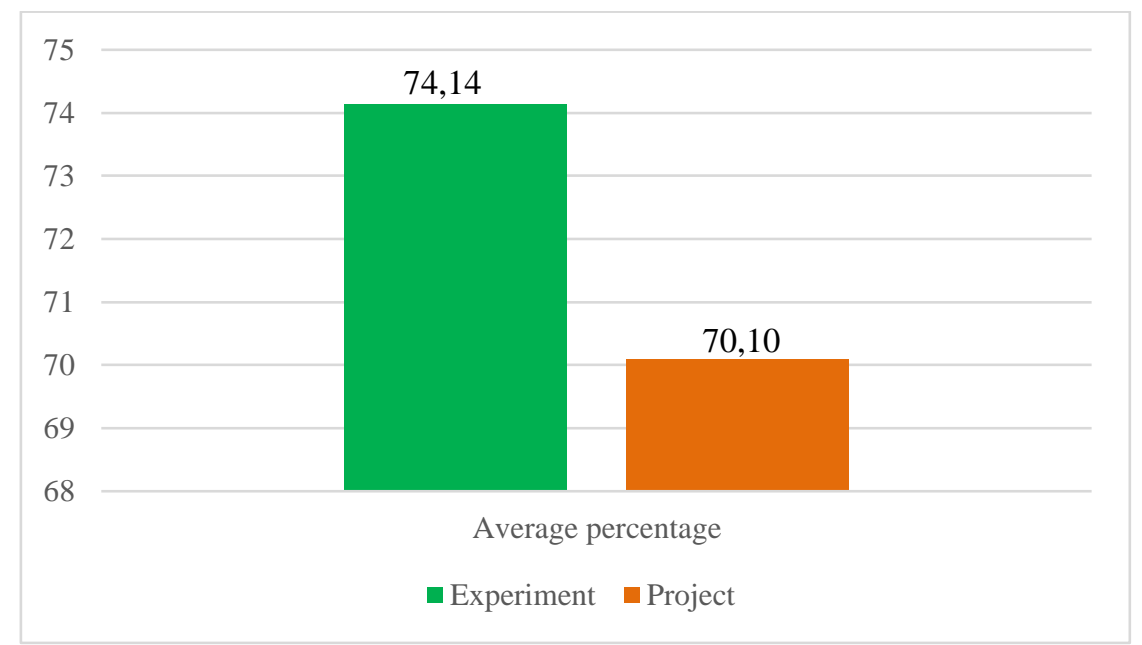

Figure 2. The Average Results of the Experimental Class and the Project's Scientific Attitude

Figure 2 shows the average results of the scientific attitude of the experimental class and the project class. Where the average percentage in the experimental class is 74.14 , and the project class is 70.10. In both classes, there are two categories, namely high and low categories. The following table 2 shows the high and low categories of scientific attitudes in both classes.
Table 2. Results of Scientific Attitude at High and Low Categories

\begin{tabular}{cccc}
\hline \multirow{2}{*}{ Class } & \multicolumn{2}{c}{ Category } & Total \\
& High & Low & students \\
\hline Experiment & 15 & 18 & 33 \\
Project & 16 & 16 & 32 \\
\hline
\end{tabular}

The following figure 3 shows the percentage of high and low categories of scientific attitudes in each class. 


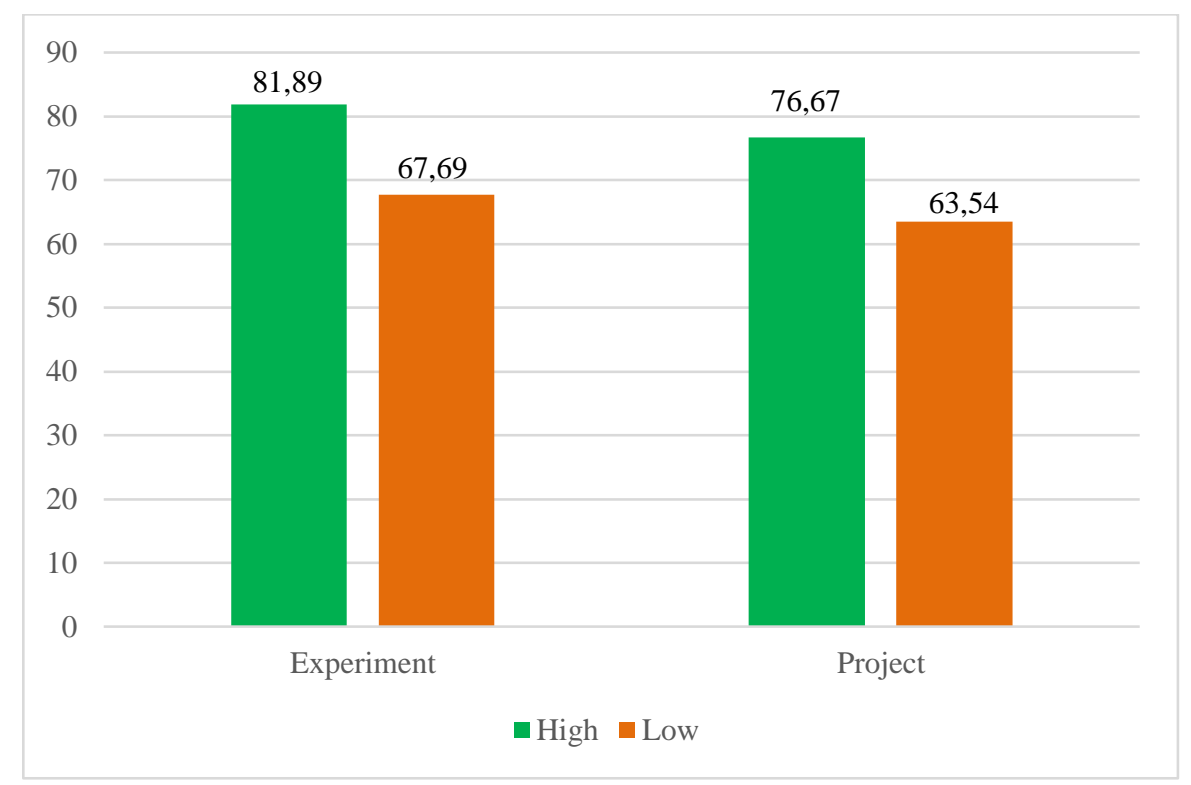

Figure 3. Average Results of High and Low Scientific Attitudes Categories

Figure 2 and Figure 3 show that the results in the experimental class are better than in the project class. The standard deviation in the high category is 4.61 , and the low category is 4.79. This is because the number of students in the low category is more than the high category. In table 2 , it can be seen that the number of students in the high category is more in the project class. However, the scores in the experimental class are still higher, namely for the high category 88.33 and for the low category 73.33, while for the experimental class, it is still higher. In the project class, the score for the high category is 83.33 , and the low category is 68.33 . This is because in learning with the experimental method, students are actively involved in simulations, increasing their learning motivation to increase curiosity and interest in physics concepts. This impacts scientific attitudes because both are internal factors, were when students have motivation (encouragement) to learn within themselves. Indirectly, they will try to process in learning so that they can hone their scientific attitudes. This agrees with (Azhari et al., 2020), who stated that students who have high learning motivation could solve problems without giving up quickly even though there are difficulties in the process. Still, they have a high scientific attitude, as evidenced by their ability to direct themselves well in learning. Student activeness in education is inseparable from their scientific attitude (Kurniawan et al., 2019).

Students are not bored when learning to understand a concept through PhET simulations better, resulting in increased scientific attitudes. This agrees with Hilliati et al., who stated that simulations in physics subjects will be more fun and will not make students bored in monotonous learning (Hilalliati et al., 2019). PhET simulations are also used easily and practically by students and get pretty high results even though the teaching is done online. Experimental virtualization and its application with internet-based distance techniques can provide a relevant and meaningful, practical learning experience (Tiwari \& Singh, 2011). This is in line with (Khairunnisak, 2018) who found that PhET makes it easier for teachers and students in the learning process to foster motivation for students and increase student understanding of concepts.

\section{a. Prerequisite Test}

1) Normality Test

This normality test uses significance $\alpha=$ 0.05 . The $p$-value data obtained is greater or equal to $\alpha=0.05$, so Ho is accepted, or it is said that the data comes from an average population. The following is a table of the 
results of the normality analysis in this research.

Table 3. Summary of Normality Prerequisite Test Results

\begin{tabular}{|c|c|c|c|}
\hline Class & $\begin{array}{c}P- \\
\text { value }\end{array}$ & Decision & Conclusion \\
\hline Experiment & 0,136 & $\begin{array}{c}\text { Ho } \\
\text { accepted }\end{array}$ & Normal data \\
\hline Project & 0,141 & $\begin{array}{c}\text { Ho } \\
\text { accepted }\end{array}$ & Normal data \\
\hline
\end{tabular}

From table 3, it can be explained that the results of the normality test for the scientific attitude of the experimental class and the project produce $\mathrm{p}>0.05$, so it can be concluded that all the data came from normally distributed populations.

\section{2) Homogeneity Test}

The homogeneity test uses the significance of $\alpha=0.05$. The $p$-value of the data obtained is greater than or equal to $\alpha=0.05$, so Ho is accepted, or it is said that the data comes from a population with homogeneous variance. The following is a table of the results of the homogeneity analysis in this research.

Table 4. Homogeneity Prerequisite Test Results

\begin{tabular}{lllll}
\hline & $\begin{array}{c}\text { Levene } \\
\text { Statistic }\end{array}$ & df1 & df2 & Sig. \\
\hline $\begin{array}{l}\text { Based on } \\
\begin{array}{l}\text { Mean } \\
\text { Based on } \\
\text { Median }\end{array}\end{array}$ & .450 & 1 & 63 & .505 \\
$\begin{array}{l}\text { Based on } \\
\begin{array}{l}\text { Median and } \\
\text { with adjusted } \\
\text { df }\end{array}\end{array}$ & .377 & 1 & 61.639 & .541 \\
$\begin{array}{l}\text { Based on } \\
\text { trimmed mean }\end{array}$ & .458 & 1 & 63 & .541 \\
\hline
\end{tabular}

Table 4, it can be explained that the data from the homogeneity test of the scientific attitude of the experimental and project classes resulted in $p>0.05$, which is 0.505 , so it can be concluded that all the data came from a homogeneous population.

\section{b. Hypothesis Testing}

The hypothesis was tested using the t-test to determine the difference in scientific attitudes in learning using the PBL model with experimental and project methods. Ttest provisions are if $p$-value $>0.05$, then the null hypothesis is accepted, whereas if the pvalue $<0.05$, then the null hypothesis is rejected. The following is a table of the results of the T-test analysis in this research.

Table 5. T-test Results

\begin{tabular}{lccccc}
\hline & $\begin{array}{c}\text { Sum of } \\
\text { Squares }\end{array}$ & \multicolumn{4}{c}{ Mean } \\
& Df & Square & F & Sig. \\
\hline $\begin{array}{l}\text { Between } \\
\text { Groups }\end{array}$ & 330.754 & 1 & 330.754 & 5.208 & .026 \\
Within & & & & & \\
Groups & 4001.156 & 63 & 63.510 & & \\
Total & 4331.911 & 64 & & & \\
\hline
\end{tabular}

From table 5, it can be explained that the data from the t-test results for the scientific attitude of the experimental class and the project produce $\mathrm{p}<0.05$, which is 0.026 , so $\mathrm{H}_{0}$ is rejected, meaning that there is a difference between the PBL model and the experimental and project methods towards scientific attitudes.

A significant difference can be seen from the average score of scientific attitudes. Students who are given learning through the PBL model with the experimental method are higher than the project method.

Physics learning is carried out in two classes, namely class I using the experimental method assisted by Phet and class II using the project method, namely assignments. However, learning with the experimental method and the project method is not much different because they both use the PBL model, in which the learning syntax in both classes is the same. Learning in the presence of concrete problems can stimulate students' thinking skills in formulating and solving problems. Static fluid material is also very close to everyday life so that students find it easier to learn and assume their opinions about things related to static fluids. 
This concurs with Kusumawati, who stated that selecting materials is also a significant obstacle to integrating problem-based learning (PBL) and experimental methods (Okyranida et al., 2017). The response of students given to the two learning methods applied is equally high. Students in the experimental group were enthusiastic about conducting experiments. The project group is also responsive to problems given by the teacher for designing project assignments. This is in line with research (Saputri, 2013) that on the project method, the students were given a problem that has never been known beforehand so that students are interested to learn. Students are only given a little help inside solve the problem. Students will be more active and creative in the process of this learning. The better the response of students to education, the better the scientific attitude.
Conversely, if the reaction of students is low, the scientific attitude will also below.

\section{Achievement of Scientific Attitudes in Learning}

The achievement of the learning model is analyzed based on indicators of scientific attitudes. To see the difference in the influence of the model and the two learning methods on students' scientific attitudes, the categories used are as follows:

Table 6. Category Scientific Attitude

\begin{tabular}{cc}
\hline Percentage interval (\%) & Category \\
\hline $81-100$ & Excellent \\
$61-80$ & High \\
$41-60$ & Moderate \\
$21-40$ & Low \\
$0-20$ & Poor \\
\hline & (Arikunto, 2010)
\end{tabular}

The following table shows a description of the scientific attitude Per dimension.

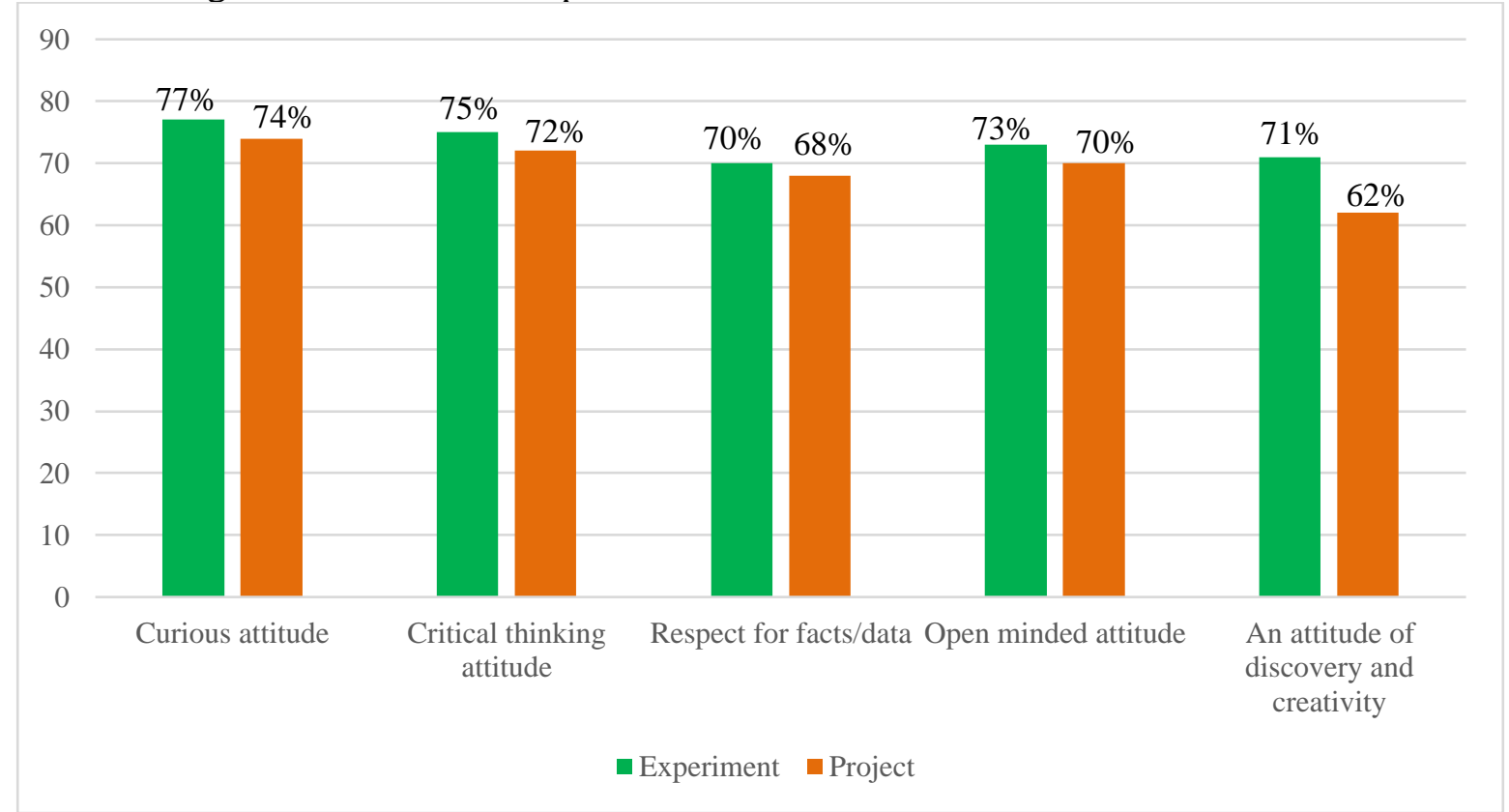

Figure 4. The Description of Scientific Attitude Per Dimension

Students in the experimental class are active and curiously looking for answers, have the critical thinking, and are open to solving problems. Some even have other references. They use the facts found to conclude. Researchers and observers perceive things slightly differently in project class. Students in the project class did show an attitude of curiosity, critical and open thinking when solving problems and drawing conclusions based on the facts found but not as well as students in the experimental class.

Figures 4 and 5 show that based on the descriptions of students' scientific attitudes in the two classes, the experimental class leads better results than the project class. In 
learning, the two classes are given different treatments, where Phet simulations are more effective concepts and can train students' scientific attitudes. This is in line with research that found that learning with the help of PhET showed high results for students' scientific attitudes.

The following table shows a description of the scientific attitude per indicator.

Table 7. Description of Scientific Attitude

\begin{tabular}{|c|c|c|c|c|c|}
\hline \multirow[t]{2}{*}{ No } & \multirow[t]{2}{*}{ Indicator } & \multicolumn{2}{|c|}{$\begin{array}{l}\text { PBL- } \\
\text { Eks }\end{array}$} & \multicolumn{2}{|c|}{$\begin{array}{l}\text { PBL- } \\
\text { Pro }\end{array}$} \\
\hline & & $\%$ & $\mathrm{~K}$ & $\%$ & $\mathrm{~K}$ \\
\hline 1 & $\begin{array}{l}\text { Asking if there are } \\
\text { things that are not } \\
\text { understood }\end{array}$ & 80 & B & 73 & B \\
\hline 2 & $\begin{array}{l}\text { Showing } \\
\text { enthusiasm for the } \\
\text { learning process }\end{array}$ & 76 & B & 77 & B \\
\hline 3 & $\begin{array}{l}\text { Showing attention } \\
\text { to the object being } \\
\text { observed }\end{array}$ & 76 & B & 73 & B \\
\hline 4 & $\begin{array}{l}\text { Repeating the } \\
\text { activities carried } \\
\text { out }\end{array}$ & 63 & B & 61 & B \\
\hline 5 & $\begin{array}{l}\text { Showing } \\
\text { skepticism, which } \\
\text { is not easy to } \\
\text { accept ideas or } \\
\text { ideas unless they } \\
\text { have been able to } \\
\text { prove their truth }\end{array}$ & 81 & $\begin{array}{l}\text { B } \\
S\end{array}$ & 74 & B \\
\hline 6 & $\begin{array}{l}\text { Showing evidence } \\
\text { of evidence to } \\
\text { draw conclusions }\end{array}$ & 80 & B & 80 & B \\
\hline 7 & $\begin{array}{l}\text { Showing an } \\
\text { objective attitude } \\
\text { in data collection }\end{array}$ & 68 & B & 63 & B \\
\hline 8 & $\begin{array}{l}\text { Showing honesty } \\
\text { in making data and } \\
\text { decisions } \\
\text { according to facts } \\
\text { and does not mix } \\
\text { facts and opinions }\end{array}$ & 71 & B & 73 & B \\
\hline 9 & $\begin{array}{l}\text { Showing respect } \\
\text { for the findings of } \\
\text { others }\end{array}$ & 76 & B & 72 & B \\
\hline 10 & $\begin{array}{l}\text { Showing the } \\
\text { attitude of not } \\
\text { feeling the most } \\
\text { right and } \\
\text { respecting the } \\
\text { opinions of others }\end{array}$ & 70 & B & 69 & B \\
\hline 11 & $\begin{array}{l}\text { Suggesting new } \\
\text { experiments }\end{array}$ & 69 & B & 60 & B \\
\hline
\end{tabular}

\begin{tabular}{clccccc}
\hline \multirow{2}{*}{ No } & \multicolumn{1}{c}{ Indicator } & \multicolumn{2}{c}{ PBL- } & \multicolumn{2}{c}{ PBL- } \\
& & $\%$ & $\mathrm{~K}$ & $\%$ & $\mathrm{~K}$ \\
\hline 12 & $\begin{array}{l}\text { Outlining new } \\
\text { conclusions from } \\
\text { the observations }\end{array}$ & 69 & $\mathrm{~B}$ & 56 & $\mathrm{C}$ \\
13 & $\begin{array}{l}\text { Using facts to base } \\
\text { conclusions }\end{array}$ & 76 & $\mathrm{~B}$ & 70 & $\mathrm{~B}$ \\
\hline Average & $\mathbf{7 3}$ & $\mathbf{B}$ & $\mathbf{6 9}$ & $\mathrm{B}$ \\
\hline
\end{tabular}

Table 7 shows that based on the results of the descriptions of students' scientific attitudes per indicator in the experimental class is better than the project class. The results obtained are pretty high because the average achievement of the scientific perspectives of the two classes is in a high category. In learning, students are given problems that can stimulate thinking skills and abilities and scientific attitudes of students during the investigation. This is in line with the research conducted by Prastika et al. that after the PBL model was applied, all indicators of students' scientific attitudes were in a high category (Prastika et al., 2019). Thus, the PBL model with experimental and project methods is effective for training students' scientific attitudes in learning physics.

\section{CONCLUSION AND SUGGESTION}

The scientific attitude of students of SMA YPPK Teruna Bakti shows a difference in the average scientific attitude between students who are given learning using the PBL model with the experimental method and students who are given learning using the PBL model with the project method. The mean scores for both are not significantly different, namely in the experimental class 74.14 and the project class 70.10. This is because the use of the PBL model with the project method is something new that students know compared to the PBL model with the experimental method that is often applied by teachers in learning physics in class. Another factor is the direct involvement of students in the learning process. The PBL model, which is applied in the classroom online, facilitates students to solve problems and discover for themselves the concept of hydrostatic pressure, Pascal's law, and Archimedes law 
that are being studied by observing in a real environment.

Online physics learning requires moderate extra preparation starting from teaching materials, virtual experiments, and other media. The teaching and learning process and the results obtained are high and improved. Learning using the PBL model with experimental and project methods is expected to be applied to other physics materials to determine students' scientific attitudes.

\section{ACKNOWLEDGMENT}

The authors express sincere gratitude and appreciation to all those who have helped in doing this research, especially to all teachers and students SMA YPPK Teruna Bakti Jayapura partaking in the research process.

\section{REFERENCES}

Anwar, H. (2009). Penilaian sikap llmiah dalam pembelajaran sains. Jurnalpelangi Iimu, 2(5), 103-113. http://ejurnal.ung.ac.id/index.php/JPI/ar ticle/view/593/544

Amelia, R., Supriyati, Y., \& Indrasari, W. (2019). The effect of SETS learning model and scientific attitude toward student's physics achievement. 8(3), 375-382.

Arikunto, S. (2010). Dasar-dasar Evaluasi Pendidikan Edisi Dua. Jakarta: Bumi Aksara.

Arini, A. N., Hartono, \& Khumaedi. (2018). Analysis of problem-solving skills and students scientific attitudes through the implementation of problem based learning module. Journal of Innovative Science Education, 7(2), 68-75.

Azhari, S., Suastra, I. W., \& Sudiatmika, A. A. I. A. R. (2020). Hubungan antara motivasi belajar dan sikap ilmiah dengan prestasi belajar fisika siswa kelas XI IPA SMA negeri 2 Denpasar. Jurnal Pendidikan Fisika Undiksha, 10(2), 91. https://doi.org/10.23887/jjpf.v10i2.286 88
Azmi, M. K., Rahayu, S., \& Hikmawati, H. (2016). Pengaruh model problembased learning dengan metode eksperimen dan diskusi terhadap hasil belajar fisika ditinjau dari sikap ilmiah siswa kelas $\mathrm{X}$ MIPA SMAN 1 Mataram. Jurnal Pendidikan Fisika dan Teknologi, 2(2), 86-94. https://doi.org/10.29303/jpft.v2i2.294

De Jong, T., \& Van Joolingen, W. R. (1998). Scientific discovery learning with computer simulations of conceptual domains. Review of Educational Research, 68(2), 179-201. https://doi.org/10.3102/003465430680 02179

Djamarah, S.B., \& Zain A. (2010). Strategi belajar mengajar. Jakarta: Rineka Cipta.

Duch, B. J., Allen, D. E., \& Groh, S. E. (1996). The power of problem-based learning. New Directions for Teaching and Learning, 1996(68), 43-52.

Hilalliati, N., Jumadi, Wilujeng, I., \& Kuswanto, H. (2019). Scientific attitudes mapping of students after using $\mathrm{PhEt}$ assisted group investigation models. Journal of Physics: Conference Series, 1233(1). https://doi.org/10.1088/17426596/1233/1/012050

Istikomah, H., Hendratto, S., Bambang, S. (2010). Penggunaan model pembelajaran group investigation untuk menumbuhkan sikap ilmiah siswa. Jurnal Pendidikan Fisika Indonesia, 6(1) 40-43. https://doi.org/10.15294/jpfi.v6i1.110 1

Khairunnisak. (2018). Peningkatan pemahaman konsep dan motivasi belajar siswa melalui simulasi physic education technology (PhET). Jurnal Penelitian Pendidikan IPA, 4(2) 7-12.

Kurniawan, D. A., Astalini, A., \& Sari, D. K. (2019). An evaluation analysis of students' attitude towards physics learning at senior high school. Jurnal Penelitian dan Evaluasi Pendidikan, 
23(1),

$26-35$. https://doi.org/10.21831/pep.v23i1.208 21

Lestari, D. I., \& Projosantoso, A. K. (2016). Pengembangan media komik IPA model PBL untuk meningkatkan kemampuan berfikir analitis dan sikap ilmiah. Jurnal Inovasi Pendidikan IPA, 2(2), $145-155$. https://doi.org/10.21831/jipi.v2i2.7280

Maulidah, S. S., \& Prima, E. C. (2018). Using physics education technology as virtual laboratory in learning waves and sounds. Journal of Science Learning, 1(3), 116. https://doi.org/10.17509/jsl.v1i3.11797

Muriithi, E. M., Odundo, P. A., Origa, J. O., \& Gatumu, J. C. (2013). Project method and learner achievement in physics in kenyan secondary schools. International Journal of Education and Research, 1(7), 1-12.

Nugraha, I., Putri, N. K., \& Sholihin, H. (2020). An analysis of the relationship between students' scientific attitude and students' learning style in junior high school. Journal of Science Learning, 3(3), 185-1. https://doi.org/10.17509/jsl.v3i3.2287 3

Okyranida, I. Y., Suparmi., \& Aminah, N. S. (2017). Pembelajaran fisika problem based learning (PBL) menggunakan metode eksperimen dan metode proyek ditinjau dari kemampuan berpikir abstrak dan kemampuan berpikir kreatif siswa SMP/MTs kelas VIII materi cahaya. Jurnal Inkuiri, 6(1), 91-102.

Pitafi, A. I., Farooq Principal, M., \& Khadizai, G. (2012). Measurement of scientific attitude of secondary school students in Pakistan. Academic Rearch International.

Prastika, M. D., Wati, M., \& Suyidno, S. (2019). The effectiveness of problembased learning in improving students scientific literacy skills and scientific attitudes. Berkala Ilmiah Pendidikan
Fisika, $\quad 7(3), \quad 194$. https://doi.org/10.20527/bipf.v7i3.7027 Ramadhani, R., Umam, R., Abdurrahman, A., \& Syazali, M. (2019). The effect of flipped-problem-based learning model integrated with LMS-google classroom for senior high school students. Journal for the Education of Gifted Young Scientists, 7(2), 137-158. https://doi.org/10.17478/jegys.548350

Riduwan. (2015). Skala pengukuran variabel-variabel. Bandung: Alfabeta Bandung.

Roestiyah. (2012). Strategi belajar mengajar. Jakarta: Rineka Cipta.

Sari, P. M., Sudargo, F., \& Priyandoko, D. (2018). Correlation among science process skill, concept comprehension, and scientific attitude on regulation system materials. Journal of Physics: Conference Series, 948(1). https://doi.org/10.1088/17426596/948/1/012008

Saputri, C. A. (2013). Pembelajaran kimia berbasis masalah dengan metode proyek dan eksperimen ditinjau dari kreativitas dan keterampilan menggunakan alat laboratorium. Jurnal Inkuiri, 2(3), 227237.

Satrianingsih, C., Shariani, S., \& Dewi, N. F. (2016). Journal of Innovative Science Education. Journal of Innovative Science Education, 1(1), 1-9.

Setyorini, U., Sukiswo, S. E., \& Subali, B. (2011). Penerapan model problem based learning untuk SMP. Jurnal Pendidikan Fisika Indonesia, 7(2), 52-56. https://doi.org/10.15294/jpfi.v7i1.1070

Suparno, P. (2007). Filsafat konstruktivisme dalam pendidikan. Yogyakarta: Kanisius.

Tatli, Z., \& Ayas, A. (2013). Effect of a virtual chemistry laboratory on students achievement technologies for the seamless integration of formal and informal learning. Journal of Educational Technology \& Society, 16(1),
159-170. 
https://www.jstor.org/stable/jeductechs oci.16.1.159

Telaumbanua, D. (2017). Experimental method application in teaching. Asian Journal of Social Sciences \& Humanities, 6(4), 84-90.

Tiwari, R., \& Singh, K. (2011). Virtualization of engineering discipline experiments for an Internet-based remote laboratory. Australasian Journal of Educational Technology, 27(4), 671692. https://doi.org/10.14742/ajet.944

Widowati, A., Nurohman, S., \& Anjarsari, P. (2017). Developing science learning material with authentic inquiry learning approach to improve problem-solving and scientific attitude. Jurnal Pendidikan IPA Indonesia, 6(1), 32-40.

\section{APPENDIX}

Table 8. Examples of scientific attitude questionnaire instruments

\begin{tabular}{|c|c|c|c|c|c|}
\hline No & Statement & SS & $\mathbf{S}$ & TS & STS \\
\hline 1 & $\begin{array}{l}\text { I prefer to ask the } \\
\text { teacher if there is } \\
\text { a material that I } \\
\text { don't understand. }\end{array}$ & & & & \\
\hline 2 & $\begin{array}{l}\text { I do not like to } \\
\text { study physics by } \\
\text { experiment, } \\
\text { either virtual or } \\
\text { real laboratory }\end{array}$ & & & & \\
\hline 3 & $\begin{array}{l}\text { I like to ask the } \\
\text { teacher if there is } \\
\text { data in the } \\
\text { practicum that is } \\
\text { not following the } \\
\text { theory }\end{array}$ & & & & \\
\hline 4 & $\begin{array}{l}\text { I prefer to know } \\
\text { the answer key } \\
\text { first before } \\
\text { working } \\
\text { physics } \\
\text { problems. }\end{array}$ & & & & \\
\hline 5 & $\begin{array}{l}\text { I will give more } \\
\text { attention to each } \\
\text { object observed } \\
\text { in experiments } \\
\text { slightest object. }\end{array}$ & & & & \\
\hline
\end{tabular}

